UDC 614.4: [616.98: 578.828HIV-053.67-053.81]: 001.8 (571.620)

DOI: 10.21668/health.risk/2016.4.13.eng

\title{
METHODS FOR ASSESSING THE AWARENESS LEVEL ABOUT HIV INFECTION RISK FACTOR AMONG STUDENTS OF THE KHABAROVSK KRAI
}

\author{
I.O. Taenkova ${ }^{1}$, O.E. Trotsenko ${ }^{1}$, L.A. Balakhontseva ${ }^{1}$, A. A.Taenkova ${ }^{2}$ \\ ${ }^{1}$ Khabarovsk research institute of epidemiology and microbiology of Federal service for surveillance on customer \\ rights protection and human wellbeing, 2 Shevchenko Str., Khabarovsk, 680610, Russian Federation \\ ${ }^{2}$ Khabarovsk regional association «Health and family», 20 Pereulok Dzerzhinskogo, 281 ldg., 680020, Khabarovsk, \\ Russian Federation
}

To prevent the social diseases, including HIV infection - is one of the high-priority tasks of the public health. To assess the awareness level among the students of the Khabarovsk Krai in the age of 17-20 years about the risk factors and the HIV transmission ways, the special investigation has been held in 2016. The method of selection of respondents was random. The sampling included the first-year students of two universities and one college in the city of Komsomolsk-on-Amur (120 pers.) and two high schools and college in Khabarovsk (100 pers.). The average age of respondents was $19.2 \pm 1.04$ years. The distribution by sex: men $-33 \pm 3.17 \%$, women $-67 \pm 3.17 \%$. The comparison of the data of the previous years $(2008,2012)$ and the study in 2016 confirmed that the majority $(92 \pm$ $1.5 \%)$ of the surveyed young adults in general are well-informed about HIV, sexual and parenteral routes of transmission. However, in recent years, the share of those who consider the possibility of HIV transmission through kisses, bites of blood-sucking or by sharing a meal. The performed studies have confirmed the tendency of the younger generation to the risky behavior. Their search for novelty and the thrills can be traditionally considered to be a contributing factor to the experiments with psychoactive substances and early initiation of sexual relations. The conducted analysis has showed the possibility of using the various forms and methods of youth behavior research. The study has revealed a certain potential for preventive planning of primary prevention of HIV infection. The obtained results have demonstrated that for the effective containment of the HIV epidemic it is necessary to carry out continuous risk monitoring system and preventive work among all young people, not only among the vulnerable groups.

Key words: HIV infection, awareness, situation monitoring, risk of transmission, young adults, prevention.

Preserving young people's health and prevention of social diseases spread, including drug addiction and HIV-infection, are priority tasks of public healthcare.

An issue of HIV contagion risk among young people is always vital as young people aged 14-30 are a population group who are go- ing to pursue their course of life, choose a career, build a family, give birth to children, and, in doing so, improve social, economic, and demographic situation in our country. To detect unfavorable epidemiologic situation and to work out relevant prevention activities we need to apply a specific system of epidemiologic risks manage-

(C) Taenkova I.O., Trotsenko O.E., Balakhontseva L.A., Taenkova A.A., 2016

Irina O. Taenkova - Researcher of the Laboratory for prevention of viral hepatitis and AIDS of the Far Eastern Regional Center for Prevention and Control of AIDS (e-mail: aids_dv@ mail.ru; tel.: +7 (421) 225-31-85).

Olga E. Trotsenko - MD, Director (e-mail: trotsenko_oe@ hniiem.ru; tel.: +7 (421) 232-52-28).

Lyudmila A. Balakhontseva - Head of the Far Eastern Regional Center for Prevention and Control of AIDS (e-mail: balahonceva-la@list.ru; tel.: +7 (421) 221-66-39).

Alina A. Taenkova - PhD, scientific advisor (e-mail: docanna27@ yandex.ru; tel.: +7 (421) 221-66-39). 
ment. Morbidity index is a basic one showing HIV spread level. However, it doesn't always give an opportunity to react promptly as related data become available only in a certain period of time (a quarter, a year) $[1,9,16]$.

Unified complex approach to assessing epidemiologic situation, various factors and subjects of administrative impact allows to form target groups for preventive activities in the sphere of HIV infection spread [2,6]. Risk of catching sexual diseases and HIV-infection is especially high among young people. If we understand the awareness level and certain attitudes towards prevention of so called behavioral diseases among rising generation, we can plan educational activities and predict prevalence of socially significant diseases as well as apply other preventive measures $[8,21,22]$. A lot of publications in domestic literature $[4,5,6,9,10,23]$ as well as the authors' own data $[12,13,15]$ confirm the fact that studying level of knowledge on risks of catching HIV-infection is vital. Here it is very important to perform comprehensive analysis of changes which occur in diseases prevalence and awareness of the population about risks of their evolvement; it is also important to compare all obtained data with data from previous periods etc. $[9,11,13,14]$.

It becomes essentially vital to develop policy in the sphere of resistance to HIV-infection spread and to implement complex prevention programs aimed at mitigating medical-social and economic consequences of this social pathology. Here specialists treat effectiveness of prevention programs and medical-social programs and the educational effect level as correlated categories [3].

Hygienic education and medical-social education are very important tools for achieving epidemiologic welfare of the population. Activity in this sphere requires constant search for new information technologies which meet the contemporary challenges, population needs and needs of the country as a whole $[4,18,23]$. To work out prevention strategy and information and education activities methodology we require not only data on pathological affection but also social and psychological data. And here studying behavioral patterns with the consequent compar- ative analysis of the obtained data and data from previous periods is of primary importance.

Our research goal was to assess level of awareness which young students (aged 17-20) in Khabarovsk region had of risk factors and ways of catching HIV-infection. To do this, we applied a combination of social techniques and social and psychological ones.

Data and methods. Traditionally, level and dynamics of HIV-infection morbidity are analyzed on the basis of state statistic reports as well as via performing various studies of behavioral practices. The authors have accumulated certain experience in collecting and analyzing the data which are necessary to work out a preventive strategy and to plan medical and sanitary education on decreasing prevalence of social diseases among young people [15].

Figure represents a scheme of various forms and techniques which give the opportunity to assess level of young people's awareness of HIV-infection contagion risks directly or indirectly.

To carry out research in 2016 we used formalized questioning technique among young students in two cities of Khabarovsk region, namely Khabarovsk and Komsomolskna-Amure. 220 first-year-students from educational establishments of higher education and secondary vocational education aged 17-20 were our research object. We chose our respondents randomly. Our sampling included first-year students from two higher education establishments and one technical college in Komsomolsk-na-Amure (120 people) and two higher education establishments and one technical college in Khabarovsk (100 people). Average age of the respondents amounted to 19.2 \pm 1.04 years. Distribution as per sex was as follows: $33 \% \pm 3.17$ males, $67 \% \pm 3.17$ females.

We used a structured questionnaire as our toolset; it consisted of 17 multiple choice questions, each having from 3 to 7 answer variants. Questions were divided into two groups; the first one was dealing with HIV infection epidemiology and was related to contagion ways, risk behavior (taking psychoactive drugs, early sexual contacts with often change of partners etc.); the second group contained 
social and psychological questions aimed at detecting attitudes towards safe sexual behavior, being ready to use protective measures and to be regularly HIV-tested. Besides, we analyzed social and demographic features of our respondents (sex and age).

We used some supplementary techniques; they included specialized exercises and tests and solving subject crosswords which we had previously tried out during some events dedicated to World Health Day, for example subject classes delivered as per requests from educational establishments of Khabarovsk city. 122 students took part in our research; they all were first-year-students; their average age was $17.1 \pm 0,9$, and they all were chosen randomly. This research stage was accomplished in order to try out and confirm efficiency of applying indirect techniques when assessing level of awareness about HIV infection. We obtained the data on level of knowledge about HIV contagion ways.

To perform comparative analysis we used data obtained during sociological questioning conducted in 2008 and 2012 with the use of the same toolset and also with the use of other techniques aimed at studying awareness among young students in Khabarovsk region (first year students of HEE and technical colleges in Khabarovsk and Komsomolskna-Amure) shown in Figure. The research was accomplished by Regional Youth Social MedicalPedagogical Center; the results were included into a number of monographs and scientific articles [1,11,12]. 500 first-year-students from two HEE and two technical colleges in Komsomolsk-naAmure and three HEE and two technical colleges in Khabarovsk took part in 2008 research; in 2012 300 students from the same educational establishments participated in questioning (average age was $17.8 \pm 0.6$ years).

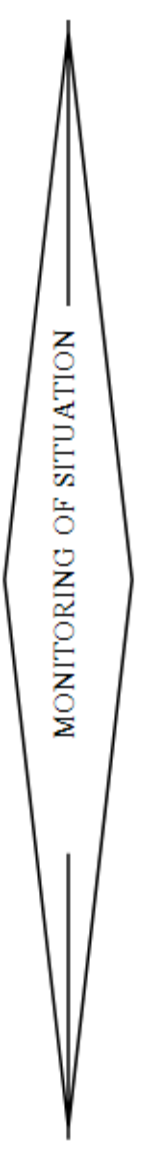

Assessing knowledge and skills via observation and interview during subject role playing and solving situational tasks

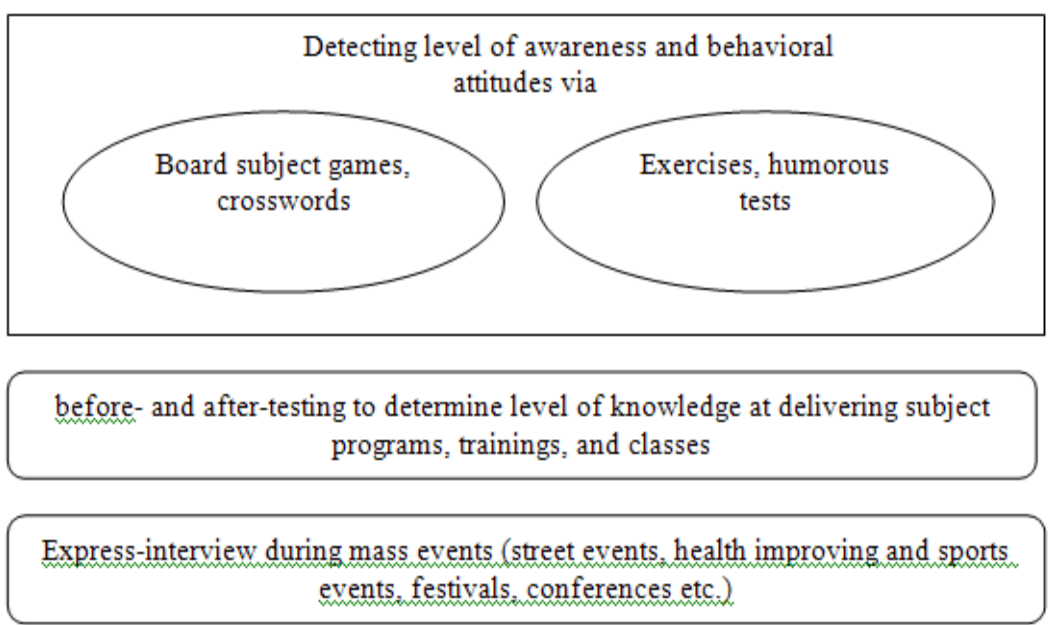

Periodical sociological research via representative questioning among various target (including vulnerable) population groups of a district, a city, or a region

Figure. Forms and methods to assess level of awareness about HIV-infection among young people 
Research results. As we compared the data from previous periods and data obtained in 2016, we saw that rising generation were really prone to risky behavior. Searching for novelty and thrills is traditionally considered to be a factor making for experiments with psychoactive drugs and early sexual contacts. For example, we can assess health risk as per variants suggested as an answer to a statement "You should try out everything in this life!". $29.0 \pm 2.52 \%$ respondents were ready to put their health at risk, $27.0 \pm 2.45 \%$ had doubts about that, $41.0 \pm 1.65 \%$ said it was completely untrue for them (2012).

Comparative analysis results revealed both positive changes and absence of them, and we understand that constant attention to young people's awareness of HIV infection spread issue is required.

Most young respondents $(92.0 \pm 1.53 \%)$ in the latest research (2016) were well aware of HIV infection choosing answer "yes, I know this infection; one can catch it and become ill with AIDS".

The research conducted in 2016 and comparison with the data obtained in 2008 revealed good awareness of sexual and parenteral (via blood) ways of HIV-infection contagion among young people. However, only $60.0 \pm 2.65 \%$ respondents knew there was also "vertical" (perinatal) contagion way. Despite all this, the awareness level among students about parenteral, sexual, and vertical way of contagion increased in 2016 in comparison with 2008 (Table 1). But it is quite alarming that over the last years the number of those believing one can catch HIV via kisses, bites of blood-sucking insects, or when sharing a meal, has been growing.

We should point out that in spite of high level of awareness about basic ways of HIVinfection contagion a great number of respondents in 2016 turned out to have phobias and to have little information about life with HIV. For example, when answering a question "Would you shake hands with a HIVinfected person?" $25.72 \pm 2.42 \%$ had doubts about that, and $4.71 \pm 1.17 \%$ said it was completely impossible. Up to $36.0 \pm 2.66 \%$ re- spondents wished to keep their distance from HIV-infected people, and $19.0 \pm 2.17 \%$ would be greatly concerned at having such s person in their group.

\section{Table 1}

Frequency of respondents' answers about possible ways of HIV-infection contagion (in \%, in different years)

\begin{tabular}{|c|c|c|c|}
\hline \multirow{2}{*}{ Questions } & \multicolumn{2}{|c|}{$\begin{array}{l}\text { Frequency (in \%) of positive } \\
\text { answers given by respondents }\end{array}$} & \multirow{3}{*}{$\begin{array}{c}p \\
\text { Probability } \\
\text { of errors in } \\
\text { parameters }\end{array}$} \\
\hline & $\begin{array}{c}2008 \\
(n=500)\end{array}$ & $\begin{array}{c}2016 \\
(n=342)\end{array}$ & \\
\hline Average age & $17,9 \pm 0,5$ & $18,15 \pm 0,8$ & \\
\hline $\begin{array}{l}\text { Ways of HIV infection } \\
\text { contagion: } \\
- \text { sexual }\end{array}$ & $86,0 \pm 1,54$ & $92,8 \pm 1,39$ & $p<0,001$ \\
\hline $\begin{array}{l}\text { - parenteral } \\
\text { (through blood) }\end{array}$ & $87,0 \pm 1,51$ & $99,0 \pm 0,53$ & $p<0,001$ \\
\hline - perinatal (vertical) & $45,0 \pm 2,21$ & $60,0 \pm 2,65$ & $p<0,001$ \\
\hline $\begin{array}{l}\text { - through bites of } \\
\text { blood-sucking insects }\end{array}$ & $20,0 \pm 1,78$ & $27,3 \pm 2,41$ & $p<0,05$ \\
\hline - via kisses & $14,0 \pm 1,54$ & $20,9 \pm 2,19$ & $p<0,01$ \\
\hline - when sharing a meal & $2,0 \pm 0,62$ & $17,81 \pm 2,04$ & $p<0,001$ \\
\hline
\end{tabular}

Table 2 contains data on dynamics in distribution of young people's answer to a question "What is necessary to prevent catching HIV-infection?" over years; as we can see from this table, level of awareness about various efficient protection measures has grown.

Table 2

Distribution of young people's answers to a question «"What is necessary to prevent catching HIV-infection?" (in \%, over years)

\begin{tabular}{|c|c|c|c|}
\hline \multirow[t]{2}{*}{ Variants } & \multicolumn{3}{|c|}{$\begin{array}{c}\text { Share (in \%) of respondents, who chose } \\
\text { this variant }\end{array}$} \\
\hline & 2008 г. & 2012 г. & 2016 г. \\
\hline $\begin{array}{l}\text { To avoid taking } \\
\text { drugs }\end{array}$ & $24,0 \pm 1,91$ & $49,9 \pm 2,88$ & $59,0 \pm 2,73$ \\
\hline $\begin{array}{l}\text { To have one healthy } \\
\text { partner and be faith- } \\
\text { ful to him/her }\end{array}$ & $29,0 \pm 2,02$ & $60,81 \pm 2,81$ & $54,72 \pm 2,76$ \\
\hline To use condoms & $48,0 \pm 2,23$ & $53,72 \pm 2,87$ & $52,61 \pm 2,77$ \\
\hline $\begin{array}{l}\text { To observe rules of } \\
\text { personal hygiene }\end{array}$ & $51,0 \pm 2,23$ & $45,41 \pm 2,87$ & $41,32 \pm 2,73$ \\
\hline
\end{tabular}

Note: students were allowed to choose not more than 3 variants of an answer 
Nowadays, more than a half respondents mention such priority prevention measures as giving up psychoactive drugs $(59.0 \pm 2.73 \%)$, necessity "to have one constant healthy sexual partner and to be faithful to him/her" $(54.72 \pm 2.76 \%)$, using condoms to protect oneself from contagion $(52.61 \pm 2.77 \%)$. It is quite remarkable that a share of students who believe that "you should stop taking drugs if you want to avoid HIV-infection" has grown considerably, from $24.0 \pm 1.91 \%$ in 2008 to $59.0 \pm 2.73 \%$ in $2016(\mathrm{p}<0.001)$.

In our opinion, there are several reasons for that. First, it is due to complex large-scale prevention activities which took place in the region and were performed by prevention system establishments together with law enforcement structures in 2008-2015. Secondly, young people mostly changed drugs they tended to take and ways of their introduction (they switched from intravenous introduction to taking synthetic peroral drugs and smoking mixtures / spies which were more available for young people).

A share of respondents believing it was necessary to "have one healthy sexual partner and be faithful to him/her" has increased considerably in 2016 in comparison with 2008 $(\mathrm{p}<0.001)$. We can also trace a positive trend to have more responsible attitude towards one's health in using condoms. Young people have quite satisfying knowledge about condoms as a means to reduce HIV-infection risks (the share grew from $48.0 \pm 2.23 \%$ in 2008 to $52.61 \pm 2.77 \%$ in 2016 of total number of respondents); this knowledge partly transforms into safe behavior. Thus, as per questioning results, the share of young people who permanently used such protectors grew from $7.52 \pm 1.17 \%$ in 2008 to $45.15 \pm 2.69 \%$ in 2016 (of total number of respondents, $\mathrm{p}<0.001$ ).

So, the share of those who permanently use condoms as a means of protection from HIV contagion is relatively high; but still, up to $29.82 \pm 2.47 \%$ young people questioned in 2016 chose the answer "I don't need it", and $4.13 \pm 1.07 \%$ considered that "condoms can't protect from HIV". 11,25 $\pm 1,72 \%$ respondents used condoms "only when having suspicious contacts".

Regular testing can be considered a prevention measure against HIV-infection spread; scales of such testing have grown over the last years. Most young respondents $(72.0 \pm 2.82 \%)$ questioned in 2016 had HIV testing, and $52.0 \pm 2.7 \%$ of them did it in the last six months. The rest $28.0 \pm 2.16 \%$ respondents chose the answer "yes, but I don't remember when I did it". $14,12 \pm 1,88 \%$ were ready to have such test when asked during questioning ("I would have it but I wasn't offered to do it"), and $11.23 \pm 1.71 \%$ respondents chose the answer "I don't need it".

Therefore, the obtained data revealed satisfactory level of awareness about basic ways of HIV-infection contagion (sexual and parenteral one). However in the course of our research we detected that population still had some stereotypes. Thus, up to $15 \pm 3.23 \%$ respondents in 2016 thought it dangerous to share a meal with a HIV-infected person, and $23 \pm 3.8 \%$ believed one could catch HIV through bites of blood-sucking insects.

It is next to impossible to conduct largescale sociological research annually; but it is quite possible to apply various techniques described in this article which are more available and can be aimed at monitoring of the situation. Such monitoring is necessary for prompt responses when implementing systems of primary prevention activities and detecting most vulnerable age or social group who are priority target for educational activities.

Conclusions. Analysis of the level of awareness among young people about possible ways of catching HIV-infection proves potential efficiency of medical and sanitary education. Most young people, just like in previous years, are well aware of basic ways of HIVinfection contagion. At the same time we are worried that there are still myths existing in young people's minds telling that it is possible to catch HIV via kisses or bites of bloodsucking insects. It calls for paying greater attention to destruction of such myths when implementing prevention programs. It can be 
achieved through situational role-playing and application of various exercises / role-playing games. There is additional reserve in using HIV-testing as a prevention technique.

The novelty of our last research can be seen in detection of certain prevention potential which recognized risks have in terms of primary prevention against HIV-infection contagion. Thus, most young people assign top priority as per protectors rating scale to such convictions as "to have one constant healthy partner and to be faithful to him/her", "to give up taking drugs", and "to use condoms" $(54.72 \pm 2.76 \% ; 59.0 \pm 2.73 \% ; 52.61 \pm 2.77 \%$ correspondingly). Up to $33.9 \pm 2.55 \%$ respondents still don't see any relation between protection from HIV and the necessity to permanently use condoms. Mostly girls and young women had little interest in using condoms.

The success of prevention activities against HIV-infection spread depends on their coordination. There is no universal algorithm of prevention activities. However, it is possible and, moreover, necessary to work out common approaches to organizing and carrying out such events [7]. Coordination aiming of prevention activities at all groups in prevention system underlies most successful prevention strategies. The obtained results again revealed that to restrain HIV epidemic efficiently, it is necessary to conduct continuous risks monitoring among all the young people and not only among most vulnerable population groups. And here medical and sanitary education should be aimed at both formation of spiritual, moral, and family values, and safe sexual behavior with correct use of protectors against HIV.

The performed analysis showed efficiency of various techniques applied in the course of studying behavioral practices in order to determine further management decisions which are needed to reduce risks of HIV-infection contagion among young people.

\section{References}

1. Popova A.Ju., Zaitseva N.V., May I.V., Shur P.Z. Analiz riska zdorov'ju v zadachah sovershenstvovanija sanitarno-jepidemiologicheskogo nadzora v Rossijskoj Federacii [Methods and technologies of health risk analysis in the system of state management under assurance of the sanitation and epidemiological welfare of population]. Gigiena $i$ sanitarija, 2015, vol. 94, no. 2, pp. 93-98 (in Russian).

2. Bulan'kov Ju.I., Orlov E.S. Napravlenija protivodejstvija rasprostraneniju VICh-infekcii i social'noznachimyh zabolevanij v molodezhnoj srede [Directions to counter the spread of HIV infection and socially significant diseases among youths]. Deti i VICh: problemy i perspektivy: materialy konferencii [Children and HIV: challenges and prospects: materials of the conference]. St. Petersburg, Chelovek i ego zdorov'e Publ., 2014, pp. 62-64 (in Russian).

3. Zelenov V.V., Mazus A.I., Duhanina I.V., Chigrinec O.V., Vinogradov D.L. Voprosy politiki protivodejstvija rasprostraneniju narkomanii i VICh-infekcii [Aspects of the policy on combating the spread of drugs and HIV/aids infection]. Voprosy narkologii. 2009, no. 2, pp. 96-105 (in Russian).

4. Gumenjuk V.T., Fetisova G.K. Opyt vnedrenija novyh informacionnyh tehnologij i metodicheskih podhodov $\mathrm{v}$ provedenii gigienicheskogo vospitanija i obuchenija naselenija [The experience of the introduction of new information technologies and methodological approaches in conducting of hygiene education and training of the population]. Zdorov'e naselenija i sreda obitanija, 2016, vol. 275, no. 2, pp. 52-55 (in Russian).

5. Zaitseva N.V., May I.V., Shur P.Z. Analiz riska zdorov'ju naselenija na sovremennom jetape [Health risk analysis at the recent stage]. Zdravoohranenie Rossijskoj Federacii, 2013, no. 2, pp. 20-24 (in Russian).

6. Kalacheva G.A., Levahina L.I., Jastrebov V.K. Biopovedencheskie issledovanija v ujazvimyh gruppah po VICh-infekcii v regionah Sibirskogo federal'nogo okruga [Biobehavioral research among vulnerable groups for HIV infection in regions of the Siberian Federal region]. Zdorov'e naselenija i sreda obitanija, 2016, vol. 277, no. 4, pp. 45-47 (in Russian). 
7. Koncevaja A.V., Kalinina A.M., Grigorjan C.A. Povedencheskie faktory riska i ih korrekcija v organizovannyh kollektivah [Behavioral risk factors and their correction in organized collective bodies]. Profilakticheskaja medicina, 2009, no. 4, pp. 8-15 (in Russian).

8. Korshunov V.A. Ocenka otnoshenija studentov k svoemu zdorov'ju i verojatnosti ih vovlechenija v potreblenie narkotikov [The estimation of student"s health behavior and risk of involvement in drug use among them]. Zdorov'e naselenija i sreda obitanija, 2016, vol. 277, no. 4, pp. 8-10 (in Russian).

9. Lebedeva-Nesevrya N.A. Metodicheskie voprosy ocenki riska, svjazannogo s vozdejstviem povedencheskih faktorov na zdorov'e naselenija [Methodical questions on assasment of risk associated with behavioral factors' im-pact on population health]. Health Risk Analysis, 2016, no. 2, pp. 10-18. DOI: 10.21668/health.risk/2016.2.02.eng (in Russian).

10. Novikova Ju.B., Shuljak Ju.A., Demidovich L.I. Ocenka urovnja znanij o vozmozhnosti zarazhenija, lechenija i profilaktiki parenteral'nyh gepatitov V i S, VICh-infekcii sredi pacientov narkologicheskogo stacionara [Assessing the level of knowledge about the possibility of infection, treatment and prevention of parenteral hepatitis $\mathrm{B}$ and $\mathrm{C}, \mathrm{HiV}$ infection among patients in addicted hospital]. Jepidemiologija i infekcionnye bolezni, 2012, no. 2, pp. 14-19 (in Russian).

11. Plotnikova Ju.K., Ponotova L.V., Malov I. V. Modelirovanie sociologo-jepidemiologicheskogo riska kak osnovy jeffektivnogo upravlenija territorial'noj sistemoj bor'by i profilaktiki VICh/SPID zabolevanija [Modelling the sociological and epidemiological risk as the base for effective management of territorial system of struggle and preventive measures against HIV/AIDS disease]. Sibirskij medicinskij zhurnal (Irkutsk), 2012, no. 1, pp. 83-87 (in Russian).

12. Struin N.L., Beljavskij A.R., Struina N.N. Sistema upravlenija riskami pri social'no znachimyh infekcijah [Epidemiological risk management system of socially significant infections]. Zdorov'e naselenija i sreda obitanija, 2016, vol. 275, no. 2, pp. 20-24 (in Russian).

13. Taenkova A.A. Reproduktivnoe povedenie molodezhi Priamur'ja i vozmozhnosti medikosocial'noj raboty po ego formirovaniju: monografija [Reproductive behavior of young people in Amur region and medical and social possibilities for its shaping: monograph]. Vladivostok, Dal'press Publ., 2008, 204 p. (in Russian).

14. Taenkova A.A., Taenkova I.O. Zdorovyj obraz zhizni molodezhi Habarovskogo kraja: sovremennaja situacija i strategija mediko-social'noj i profilakticheskoj raboty: monografija [Healthy lifestyle of the youths in Khabarovsk Krai: present situation and strategy of medical and social preventive work: monograph]. Khabarovsk, Media-most Publ., 2013, 124 p. (in Russian).

15. Taenkova A.A., Taenkova I.O. Povedencheskie bolezni molodezhi Habarovskogo kraja: jepidemiologija rasprostranenija i sovremennye vozmozhnosti profilakticheskoj raboty: monografija [Behavioral diseases of the young adults of Khabarovsk Krai: epidemiology expansion and modern possibilities of preventive work: monograph]. Khabarovsk: Khabarovskaya kraevaya tipografiya Publ., 2009, 148 p. (in Russian).

16. Shigan E.E. Istorija vozniknovenija ponjatija «risk zdorov'ju» i ego mesto v razvitii profilakticheskoj mediciny [History of "health risk" and its place in the development of preventive medicine]. Health Risk Analysis, 2016, no. 2, pp. 4-10. DOI: 10.21668/health.risk/2016.2.01.eng (in Russian).

17. Adolescents: health risks and solution. World Health Organization, 2016, no. 345. Available at: http: //www.who.int/mediacentre/factsheets/fs345/en (05.07.2016).

18. Behavior Risk Factor Surveillance System Questionnaire, 2013, 64 p. Available at: http: //www.cdc.gov./

brfss/questionnaires/pdf-ques/2014_brfss.Pdf (11.07.2016).

19. Lutz W., Butz W., Samir R.C., Sanderson W., Scherbov S. Hjhulation growth: Peak probability. Science, 2014, vol. 346, no. 6209, pp. 561.

20. Justin M.C., Wilson M.L., Allison E.A. Analysis of social epidemiology research on infectious diseases: historical patterns and future opportunities. J. Epidemiol. Community Health, 2007, no. 61, pp. $1021-1027$.

21. Krämer A., Kretzschmar M., Krickeberg K. Modern Infectious Disease Epidemiology: Concepts, Methods, Mathematical Models, and Public Health. Statistics for Biology and Health. New York, Springer Publ., 2010, pp. 101-115. 
22. Parker, Richard, Delia Easton, and Charles H. Klein. Structural Barriers and Facilitators in HIV Prevention: A Review of International Research. AIDS, 2000, vol. 14, no. 1, pp. $22-32$.

23. Sumartojo E. Structural factors in HIV prevention: concepts, examples, and implications for research. AIDS, 2000, vol. 14, pp. 3-10.

Taenkova I.O., Trotsenko O.E., Balakhontseva L.A., Taenkova A.A. Methods for assessing the awareness level about hiv infection risk factor among students of the Khabarovsk krai. Health Risk Analysis, 2016, no. 4, pp. 110-117. DOI: 10.21668/health.risk/2016.4.13.eng

Received: 17.09 .2016

Accepted: 19.12.2016

Published: 30.12.2016 